\title{
Alcohol-Based Fixatives can Better Preserve Tissue Morphology than Formalin
}

\author{
Fijadores a Base de Alcohol Pueden Preservar \\ Mejor la Morfología Tisular que la Formalina
}

\section{Ziaul Haque ${ }^{1}$; Md. Asabur Rahman'; Md. Zahirul Islam Khan'; Mohammad Tufazzal Hussan² \& Md. Mahmudul Alam ${ }^{3}$}

HAQUE, Z.; RAHMAN, M. A.; KHAN, M. Z. I.; HUSSAN, M. T. \& ALAM, M. M. Alcohol-based fixatives can better preserve tissue morphology than formalin. Int. J. Morphol., 38(5):1371-1375, 2020.

SUMMARY: Fixation is a crucial step in processing of tissue specimen for preservation of cellular architecture and composition of cells. Alcohol-based fixatives are considered some of the most promising alternatives to formalin. We evaluated the performance of alcohol-based fixatives (EthMeth and methacarn) and formalin as a comparator fixative in the research laboratory. Following 24 hours of fixation, tissue morphology and cellular details of the liver, spleen and brain (cerebral cortex) were evaluated. Morphological characteristics were evaluated by gross observations and analyzing cellular details, tissue architecture and overall staining characteristics (Hematoxylin and Eosin). EthMeth and methacarn fixation gave generally comparable and satisfactory results on the tissue morphology and subsequent identification of tissue characteristics. Particularly, tissues were well preserved and all nuclear as well as cytoplasmic details were clearly visible. However, formalin fixed tissues showed some peculiarity such as improper fixation, mild shrinkage, and alterations of tissue components. These results confirm that alcohol-based fixation is the superior alternative to formalin for preservation of tissue morphology. However, it is required to standardize the formalin-free methods and harmonize diagnosis in the laboratory worldwide.

KEY WORDS: Fixation; EthMeth; Methacarn; Formalin; Tissue morphology.

\section{INTRODUCTION}

Fixation is an essential step to prevent autolysis and degradation of tissues, while preserving morphology and cellular details for microscopic evaluations. It helps to preserve cellular architecture and composition of cells in the tissue to allow them to withstand subsequent processing. Fixation also preserves the proteins, carbohydrate and other bio-active moieties in their spatial relationship to the cell, so that they can be studied.

An ideal fixative is expected to harden tissue components and prevent decomposition, putrefaction, and autolysis. Formalin has been used as the "gold standard" fixative for study and researches. But the employees in these settings may be at risk for high levels of exposure to formalin. In particular, anatomists, histologists, pathologists, and medical students are the individuals most frequently exposed to formalin in dissection lectures and laboratories (Cohen $e t$ al., 1998; Sarnak et al., 1999). Because of this issue, the selection of a particular fixative generally warrants multiple and careful considerations. To date, no ideal fixative has been found, i.e., a safe fixative that perfectly preserves cellular morphology and yet does not modify the specimen composition so as not to change the reactivity of the chemical moieties therein for subsequent detection.

For decades, $10 \%$ formalin ( $4 \%$ formaldehyde), diluted in water or in a buffered solution has been considered as a fixative of choice in routine histopathology to preserve tissue specimens for long periods of time at reasonable cost. Formaldehyde is a toxic, potent carcinogen for public health (Baan et al., 2009; National Research Council, 2011). Formalin creates covalent bonds between biological macromolecules and ensures chemical activity conservation in tissues (Warmington et al., 2000). With a fast penetration, formalin is a slow and reversible fixative that requires 24 to 48 hours to completely bind to tissues (Srinivasan et al., 2002; Buesa, 2008). It causes cross linking of cellular proteins that masks antigenic sites for subsequent tests and

${ }^{1}$ Department of Anatomy and Histology, Faculty of Veterinary Science, Bangladesh Agricultural University, Mymensingh-2202, Bangladesh.

${ }^{2}$ Department of Anatomy and Histology, Faculty of Animal Science and Veterinary Medicine, Patuakhali Science and Technology University, Babugonj, Barisal-8210, Bangladesh.

${ }^{3}$ Department of Surgery and Obstetrics, Faculty Veterinary Science, Bangladesh Agricultural University, Mymensingh-2202, Bangladesh. 
degrades nucleic acids rapidly (Cox et al. 2006; Moelans et al., 2011a,b). Several proteolytic or heat-induced antigen retrieval methods have been recently become available through commercial sources, with the purpose of restoring normal protein folding and to improve epitope accessibility on fixed tissues (Paavilainen et al., 2010; Fowler et al., 2011). All alcoholic fixatives are fast, less toxic, act by coagulation and don't mask antigenic sites (Stanta et al., 2006). Fast fixation, optimal preservation of DNA, RNA and proteins and a safer workplace environment, are some of the advantages of alcoholic fixation over formalin fixation (Bostwick et al., 1994; Moelans et al., 2011a). But use of formalin substitutes has been restricted to a few laboratories, and reports about them are scarce. Therefore, the present study is designed to examine the efficacy of presumably less toxic alcohol based fixatives as potential substitute to formalin.

\section{MATERIAL AND METHOD}

The research experiment was conducted in the Department of Anatomy and Histology, Faculty of Veterinary Science, Bangladesh Agricultural University, Mymensingh2202, as per approval of the Animal Care and Ethics Committee.

Preparation of fixatives. Two different alcohol-based alternatives to formalin such as EthMeth (100\% Ethanol: 3 parts and Methanol: 1 part); Methacarn (100\% methanol: 6 parts, chloroform: 3 parts, glacial acetic acid: 1 part) and 10 $\%$ formalin were prepared and stored in the laboratory at room temperature for fixation of tissues.

Gross evaluation of tissues. A total of 15 adult, healthy male black Bengal goats (Capra hircus) were anaesthetized with pentobarbital sodium @ 15-20 mg/kg body weight (I/ M) and every effort was made to minimize suffering of the animals. All the animals were bled to death by giving incision on the right common carotid artery. Fixation was performed by perfusion through the carotid artery for gross evaluation of the tissues.

Histochemical evaluation of tissues. Fresh liver, spleen and brain samples were collected at the Department of Anatomy and Histology, Bangladesh Agricultural University, Mymensingh. Each tissue sample was divided into 2 equal pieces and fixed into the fixatives for 24 hours at room temperature. After fixation, tissues were processed for histochemical study. The tissues were rinsed in $70 \%$ alcohol and then processed. The processing schedule was $70 \%$ alcohol for 45 minutes, $80 \%$ alcohol for 30 minutes, 2 changes of $95 \%$ alcohol for 30 minutes each, 2 changes of $100 \%$ alcohol for 45 minutes each, 2 changes of xylene for 45 minutes each, and 4 changes of graded paraffin wax for 30 minutes each. Following embedding, each block was coded. The paraffin blocks were sectioned at $4 \mu \mathrm{m}$, and slides with tissue sections were dried in a slide warmer at $40^{\circ} \mathrm{C}$. The sections were stained using the set up as xylene-I, II \& III (3 minutes each); $100 \%$ alcohol, $95 \%$ alcohol, $80 \%$ alcohol\& $70 \%$ alcohol (3 minutes each); deionized water with gentle shaking (10 minutes); Harris Hematoxylin (10 minutes); deionized water with gentle shaking (10 minutes); Eosin-Y (2 minutes), $70 \%$ alcohol, $80 \%$ alcohol, $95 \%$ alcohol and 2 changes of $100 \%$ alcohol (3 minutes each); $50 \%$ xylene $+50 \%$ alcohol and xylene-I, II \& III ( 3 minutes each). Then the sections were coverslipped using DPX mounting medium (Lerner Laboratories, Pittsburgh, Pa) and examined under microscope.

Imaging and data analysis. The images were taken by using Nikon photomicroscope and data were analyzed by student's t-test.

\section{RESULTS AND DISCUSSION}

In this study, a group of experienced tissue morphologists examined a variety of tissue specimens fixed with formalin and 2 alcohol-based formalin substitutes (EthMeth and methacarn) without encountering significant alterations in gross morphology. Despite the fact that none of the morphologists knew which fixative had been used for section, this group of unbiased observers rated formalin and alternatives to find the best overall fixative.

On gross examination after 24 hours of fixation, all of the alcohol-based fixatives fixed tissues properly (hard and turned grey-white) except for those fixed in formalin, which turned red-brown and remained soft. The alcoholbased fixatives penetrate and fix faster than formalin. There was minor tissue contraction in case of EthMeth and formalin but not evident for Methacarn. EthMeth showed mild shrinkage with incomplete fixation which was more remarkable in formalin. Methacarn showed no shrinkage with almost complete fixation which fixed ideally. Among the fixatives, methacarn was the best preserver of tissue morphology (shape, size and consistency) followed by EthMeth and formalin. These results indicate the graded diffusion power of different fixatives in the tissues during the given period of time.

The alcohol-based fixatives preserved tissue blocks sectioned well but formalin fixed tissue blocks sectioned 
poorly. Microscopic examination of tissues was used to compare the overall effectiveness of each fixative. For this purpose, the stained tissue sections of liver, spleen and brain on the slide was examined to rate adequacy of fixation applying a scale, $1=$ poor, $2=$ fair, $3=$ good, $4=$ very good and $5=$ excellent. The slides were rated on the basis of 5 parameters: cellular outline, cytoplasmic detail, nuclear detail, overall morphology, and overall staining (Table I). In this blind study, alcohol-based fixation provided the highest histomorphologic quality for tissue stained with hematoxylin and eosin ( $\mathrm{H} \& \mathrm{E})$. The overall histologic score for alcohol-based fixatives was significantly $(\mathrm{p}<0.05)$ higher than formalin (Table II). When individual factors in fixation were studied, alcohol-based fixatives performed better than others (Table I). The methacarn provides greater staining intensity

Table I. Histological scores for formalin and alcohol-based fixatives.

\begin{tabular}{lccc}
\hline Parameters & Formalin & EthMeth & Methacarn \\
\hline Cellular outline & 2.65 & 2.86 & 3.00 \\
Cytoplasmic detail & 2.50 & 2.88 & 3.08 \\
Nuclear detail & 2.80 & 2.96 & 3.14 \\
Overall morphology & 2.84 & 2.90 & 3.10 \\
Overall staining & 2.64 & 2.93 & 3.00 \\
\hline
\end{tabular}

$1=$ poor, $2=$ fair, $3=$ good, $4=$ very good, $5=$ excellent. compared with EthMeth and formalin. In case of formalin, weak preservation with cellular degeneration and weak affinity for staining ( $\mathrm{H} \& \mathrm{E}$ ) were evident. However, methacarn preserved better cellular and intercellular structures with nice staining affinity to nuclei and cytoplasm, showing no cellular disintegration or degeneration (Figs. 1 to 3). The degree of pale staining of nuclei and cytoplasm with more or less cellular/ intercellular disintegration/degeneration were found in other fixatives. However, it was highest in the formalin fixed tissues (Figs. 1 to 3 ). These results are suggestive of alcoholic fixative as a better preserver of tissue morphology than formalin.

Alcohol-based fixatives (EthMeth and methacarn) fixed tissues ideally without significant alterations of tissue

Table II. Overall histological scores for formalin and alcohol-based fixatives.

\begin{tabular}{lccc}
\hline Fixatives & Mean & Variance & p-value \\
Formalin & 2.686 & 0.018 & \\
EthMeth & 2.906 & 0.001 & 0.015 \\
Methacarn & 3.064 & 0.003 & 0.002 \\
\hline
\end{tabular}

1 = poor, 2 = fair, 3 = good, 4 = very good, $5=$ excellent.
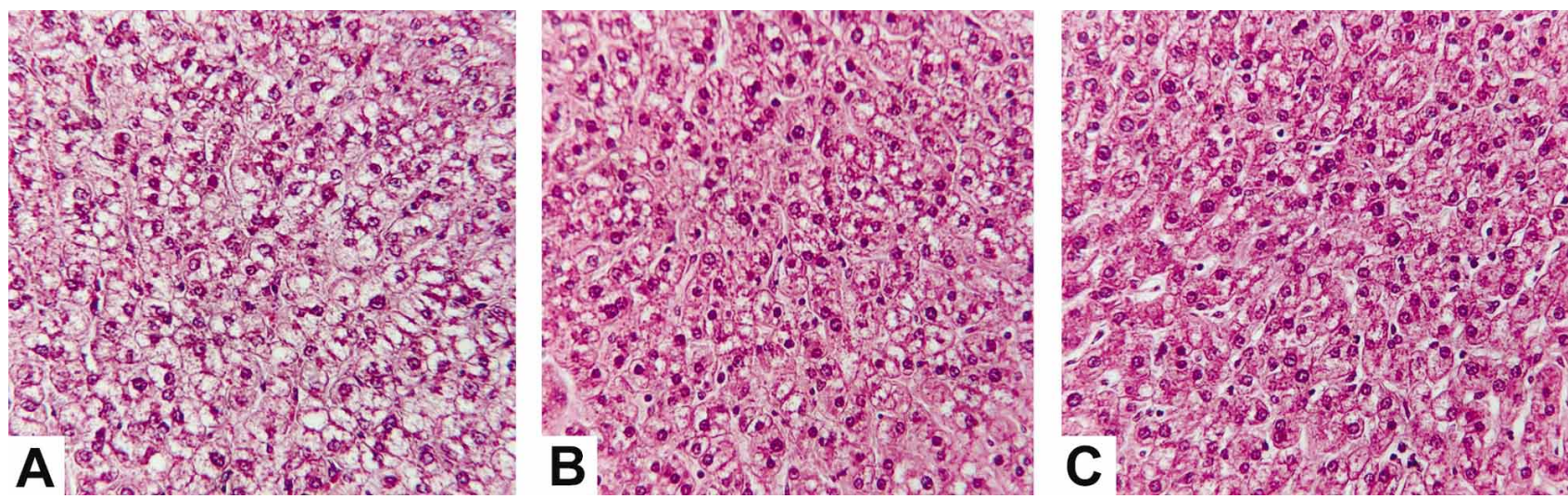

Fig. 1. Hematoxylin and Eosin (H \& E) staining of liver (40X). (A) Formalin fixed tissue (B) EthMeth fixed tissue (C) Methacarn fixed tissue.
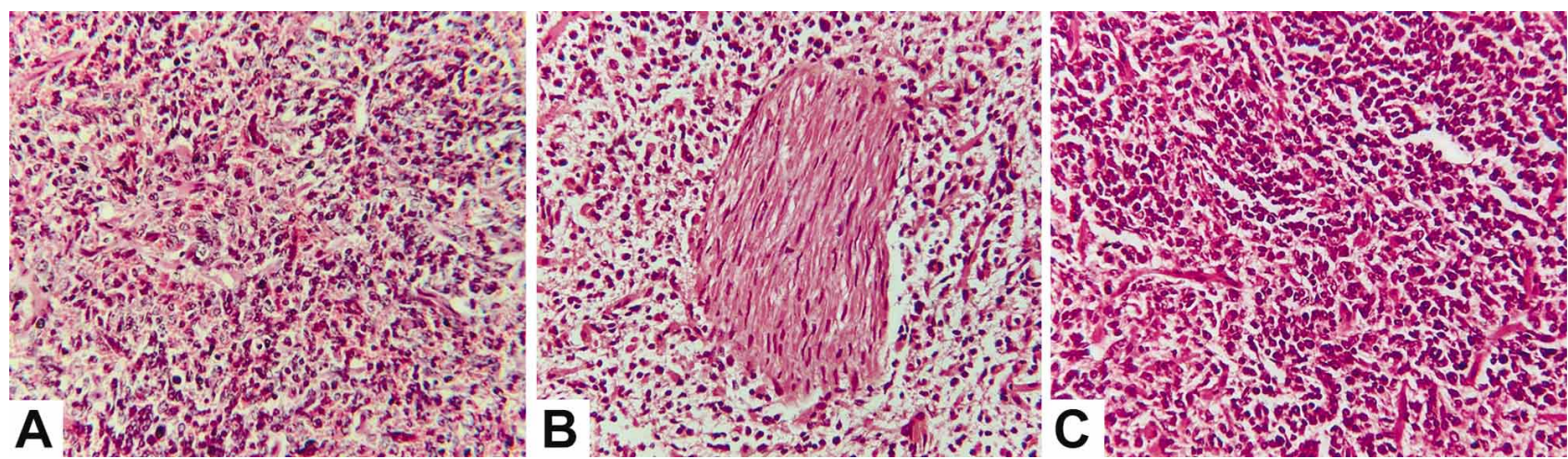

Fig. 2. Hematoxylin and Eosin (H \& E) staining of spleen (40X). (A) Formalin fixed tissue (B) EthMeth fixed tissue (C) Methacarn fixed tissue. 

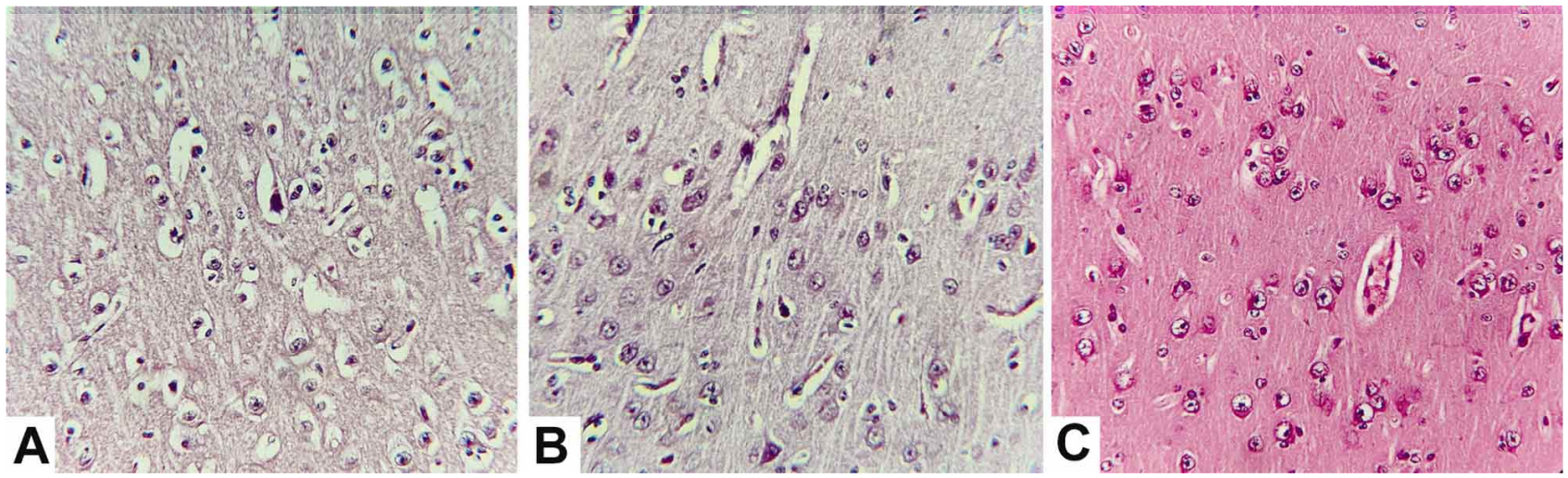

Fig. 3. Hematoxylin and Eosin (H \& E) staining of cerebral cortex (40X). (A) Formalin fixed tissue (B) EthMeth fixed tissue (C) Methacarn fixed tissue.

morphology. However, tissue appearance of formalin fixed tissues differed from alcohol-based fixatives as it caused dehydration and fixation simultaneously. Alcohol-based fixatives act by coagulation of proteins and do not mask antigenic sites as formalin does (Bancroft \& Gamble, 2008). These fixatives are faster in penetration of tissues as all these components of EthMeth and methacarn (ethanol, methanol and acetic acid) have higher coefficients of diffusibility than formalin (Kok \& Boon, 1990). Both EthMeth and methacarn preserved better general tissue morphology (gross and histomorphology) than formalin. Our results are in agreement with Buesa.

\section{CONCLUSIONS}

In our study, methacarn fixation preserved the best gross and histomorphology (H \& E) followed by EthMeth and formalin. Thus, alcohol-based fixatives can be potential alternative to formalin for preservation of tissue morphology. However, morphologists will have to familiarize themselves with a different set of microscopic details associated with alcohol-based fixatives.

\section{ACKNOWLEDGEMENTS}

We greatly acknowledge the University Grants Commission (UGC); Ministry of Science and Technology (MoST); Ministry of Education (MoE), Government of the People's Republic of Bangladesh and Bangladesh Agricultural University Research System (BAURES), Bangladesh Agricultural University (BAU), Mymensingh; for supporting the research program.
HAQUE, Z.; RAHMAN, M. A.; KHAN, M. Z. I.; HUSSAN, M. T. \& ALAM, M. M. Fijadores a base de alcohol pueden preservar mejor la morfología tisular que la formalina. Int. J. Morphol., 38(5):1371-1375, 2020.

RESUMEN: La fijación es un paso crucial en el procesamiento de muestras de tejido para preservar la arquitectura celular y la composición de las células. Los fijadores a base de alcohol se consideran algunas de las alternativas más prometedoras a la formalina. Evaluamos el rendimiento de los fijadores a base de alcohol (EthMeth y metacarn) y formalina como fijador comparativo en el laboratorio de investigación. Después de 24 horas de fijación, se observó la morfología del tejido y los detalles celulares del hígado, bazo y corteza cerebral. Se evaluaron las características morfológicas mediante observaciones generales y analizando detalles celulares, arquitectura de tejidos y características generales de tinción (hematoxilina y eosina). La fijación de EthMeth y metacarn dio resultados generalmente comparables y satisfactorios en la morfología del tejido y la posterior identificación de las características del mismo. Particularmente, los tejidos estaban bien conservados y todos los detalles nucleares y citoplasmáticos eran claramente visibles. Sin embargo, los tejidos fijados con formalina mostraron cierta peculiaridad, tal como una fijación inadecuada, la contracción leve y alteraciones de los componentes del tejido. Estos resultados confirman que la fijación a base de alcohol es la mejor alternativa a la formalina, para preservar la morfología del tejido. Sin embargo, es necesario estandarizar los métodos sin formalina y armonizar el diagnóstico en los laboratorios.

PALABRAS CLAVE: Fijación; EthMeth; Metacarn; Formalina; Morfología del tejido.

\section{REFERENCES}

Baan, Y.; Groose, Y.; Straif, K.; Secretan, B.; El Ghissassi, F.; Bouvard, V.; Benbrahim-Tallaa, L.; Guha, N.; Freeman, C.; Galichet, L.; et al. A Review of Human carcinogens--Part F: Chemical Agents and Related Occupations. Lancet Oncol., 10(12):1143-4, 2009. 
Bancroft, J. D. \& Gamble, M. (Eds.). Theory and Practice of Histological Techniques. $6^{\text {th }}$ ed. London, Churchill Livingstone, 2008.

Bostwick, D. G.; al Annouf, N. \& Choi, C. Establishment of the formalinfree surgical pathology laboratory. Utility of an alcohol-based fixative. Arch. Pathol.Lab.Med., 118(3):298-302, 1994.

Buesa, R. J. Histology without formalin? Ann. Diagn. Pathol., 12(6):38796, 2008.

Cohen, B. I.; Pagnillo, M. K.; Musikant, B. L. \& Deutsch, A. S. Formaldehyde evaluation from endodontic materials. Oral Health, 88(12):37-9, 1998.

Cox, M. L.; Schray, C. L.; Luster, C. N.; Stewart, Z. S.; Korytko, P. J.; Khan, K. N. M.; Paulauskis, J. D. \& Dunstan, R. W. Assessment of fixatives, fixation, and tissue processing on morphology and RNA integrity. Exp. Mol. Pathol., 80(2):183-91, 2006.

Fowler, C. B.; Evers, D. L.; O’Leary, T. J. \& Mason, J. T. Antigen retrieval causes protein unfolding: evidence for a linear epitope model of recovered immunoreactivity. J. Histochem. Cytochem., 59(4):366-81, 2011.

Kok, L. P. \& Boon, M. E. Microwaves for microscopy. J. Microsc., 158(3):291-322, 1990.

Moelans, C. B.; Oostenrijk, D.; Moons, M. J. \& van Diest, P. J. Formaldehyde substitute fixatives: effects on nucleic acid preservation. J. Clin. Pathol., 64(11):960-7, 2011a.

Moelans, C. B.; ter Hoeve, N.; van Ginkel, J. W.; ten Kate, F. J. \& van Diest, P. J. Formaldehyde substitute fixatives. analysis of macroscopy, morphologic analysis, and immunohistochemical analysis. Am.J. Clin. Pathol., 136(4):548-56, 2011b.

National Research Council. Review of the Environmental Protection Agency's Draft IRIS Assessment of Formaldehyde. Washington (D.C.), National Academies Press, 2011.

Paavilainen, L.; Edvinsson, A.; Asplund, A.; Hober, S.; Kampf, C.; Pontén, F. \& Wester, K. The impact of tissue fixatives on morphology and antibody-based protein profiling in tissues and cells. J. Histochem. Cytochem., 58(3):237-46, 2010.

Sarnak, M. J.; Long, J. \& King, A. J. Intravesicular formaldehyde instillation and renal complications. Clin. Nephrol., 51(2):122-5, 1999.

Srinivasan, M.; Sedmak, D. \& Jewell, S. Effect of fixatives and tissue processing on the content and integrity of nucleic acids. Am.J.Pathol., 161(6):1961-71, 2002.

Stanta, G.; Mucelli, S. P.; Petrera, F.; Bonin, S. \& Bussolati, G. A novel fixative improves opportunities of nucleic acids and proteomic analysis in human archive's tissues. Diagn. Mol. Pathol., 15(2):115-23, 2006.

Warmington, A. R.; Wilkinson, J. M. \& Riley, C. B. Evaluation of ethanolbased fixatives as a substitute for formalin in diagnostic clinical laboratories. J. Histotechnol., 23(4):299-308, 2000.
Corresponding author:

Professor Dr. Ziaul Haque

Department of Anatomy and Histology

Faculty of Veterinary Science

Bangladesh Agricultural University

Mymensingh-2202

BANGLADESH

\section{Email: zhaqueah80@bau.edu.bd}

Received: 20-12-2019

Accepted: 23-04-2020 